\title{
PENENTUAN BATAS LINEARITAS METODE PENGUJIAN AIR RAKSA DALAM AIR SECARA SPEKTROFOTOMETRI SERAPAN ATOM UAP DINGIN SESUAI SNI 6989.78 : 2011
}

\section{LIMIT OF LINEARITY DETERMINATION FOR TESTING METHOD OF MERCURY IN WATER BY COLD VAPOR ATOMIC ABSORPTION SPECTROMETRY ACCORDING TO SNI 6989.78: 2011}

\author{
Anwar Hadi ${ }^{1}$ dan Asiah ${ }^{1}$
}

(Diterima tanggal 15-09-2014; Disetujui tanggal 09-12-2014)

\begin{abstract}
ABSTRAK
Rentang kerja optimal instrumen kimia untuk mengukur kadar analit yang terkandung dalam suatu contoh uji berada diantara level of quantitation (LoQ) dan level of linearity (LoL). Umumnya, laboratorium lebih mengutamakan penetapan LoQ daripada LoL karena pelaporan hasil pengujian mensyaratkan batasan LoQ yang mampu dicapai oleh laboratorium. Penelitian ini bertujuan untuk menentukan LoL metode pengujian air raksa (Mercury, $\mathrm{Hg}$ ) dalam air dan air limbah secara spektrofotometri serapan atom sesuai SNI 6989.78: 2011 dengan kisaran kadar $1 \mu \mathrm{g} \mathrm{Hg} / \mathrm{L}$ sampai dengan $20 \mu \mathrm{g} \mathrm{Hg} / \mathrm{L}$. Secara prinsip, $\mathrm{Hg}^{2+}$ direduksi oleh $\mathrm{Sn}^{2+}$ menjadi $\mathrm{Hg}^{0}$ dan selanjutnya atom tersebut dianalisis secara kuantitatif dengan SSA - uap dingin pada panjang gelombang 253,7 nm. Penentuan LoL dilakukan dengan membuat kurva kalibrasi dari larutan standar kerja sebagai uji linearitas kurva dan dilanjutkan dengan mengukur larutan kerja $1 \mu \mathrm{g} \mathrm{Hg} / \mathrm{L}$ dan $20 \mu \mathrm{g} \mathrm{Hg} / \mathrm{L}$ sebanyak 10 kali untuk mendapatkan nilai simpangan bakunya. Data tersebut kemudian dianalisis secara statistik menggunakan analysis of varian (anova). Uji linearitas kurva kalibrasi pada penelitian ini menghasilkan nilai multiple $R=0,999$. Pada tingkat kepercayaan $99 \%$, diperoleh $\mathrm{F}_{\text {tabel }}=\mathrm{F}_{(0,01 ; 9 ; 9)}=5,351$ sehingga $\mathrm{F}_{\text {hitung }}<\mathrm{F}_{\text {tabel, }}$ maka dapat disimpulkan bahwa $1 \mu \mathrm{g} \mathrm{Hg} / \mathrm{L}-20 \mu \mathrm{g} \mathrm{Hg} / \mathrm{L}$ merupakan regresi linear dan $20 \mu \mathrm{g} \mathrm{Hg} / \mathrm{L}$ merupakan level of linearity $(\mathrm{LoL})$ dari pengukuran $\mathrm{Hg}$ menggunakan SSA uap dingin sesuai dengan SNI 6989.78:2011.
\end{abstract}

Kata kunci: batas linearitas, kurva kalibrasi, spektrofometer serapan atom (SSA), Mercury, SNI 6989.78: 2011

\begin{abstract}
Testing of samples using a chemical instrumentation has the ability to detect the range of concentration according to the sensitivity. The test method of Mercury ( $\mathrm{Hg}$ ) in water and wastewater using atomic absorption spectrophotometer (AAS) - cold vapor or Mercury analyzer in accordance with SNI 6989.78: 2011, has the working range of $1 \mu \mathrm{g} \mathrm{Hg} / \mathrm{L}-20 \mathrm{ugHg} / \mathrm{L}$. In principle, $\mathrm{Hg}^{2+}$ is reduced by $\mathrm{Sn}^{2+}$ to $\mathrm{Hg}^{0}$ and the atom further analyzed quantitatively by AAS - cold vapor at a wavelength of $253.7 \mathrm{~nm}$. Determination of the linearity test of calibration curve conducted using analysis of variance (ANOVA) and yields a multiple $R=0.999$ and significance $F=5.10^{-09}$. If the linearity test of calibration curve complies with acceptance limit, the repeatability of measurements conducted at lower level $(1 \mathrm{mg} \mathrm{Hg} / \mathrm{L})$ and high level $(20 \mathrm{ug} \mathrm{Hg} / \mathrm{L})$, and calculated the standard deviation of each in order to obtain $F$ $=3.348$. The degrees of freedom, $d f_{1}=d f_{2}=n-1$ at the $99 \%$ confidence level, so the obtained $F_{\text {table }}=F(0.01 ; 9 ; 9)$ $=5.351$. Due to $F_{\text {calculation }}<F_{\text {table }}$, it can be concluded that the $99 \%$ confidence level, $1 \mu \mathrm{g} \mathrm{Hg} / \mathrm{L}-20 \mathrm{ug} \mathrm{Hg} / \mathrm{L}$ is the linear regression and $20 \mathrm{ug} \mathrm{Hg} / \mathrm{L}$ is level of linearity (LoL) .
\end{abstract}

Keywords: level of linearity (LoL), calibration curve, atomic absorption spectrophotometer (AAS), Mercury, SNI 6989.78: 2011.

${ }^{1}$ Pusarpedal- KLH, Kawasan Puspiptek, Serpong - Banten 15310, Email : cak_war@yahoo.com. 


\section{PENDAHULUAN}

Penentuan kadar analit dalam contoh uji dapat dilakukan secara konvensional dengan menggunakan metode titrimetri atau gravimetri. Pengujian dengan cara tersebut membutuhkan keterampilan individu dan jaminan ketertelusuran metrologi yang sangat rumit. Kemajuan teknologi memungkinkan pengujian analit dalam sampel beralih menggunakan peralatan analisis kimia modern, diantaranya spektrofotometer UVVis, spektrofotometer serapan atom (SSA) dan gas kromatograf. Kadar analit dalam contoh uji yang memiliki kadar sangat kecil yang tidak mungkin diuji dengan metode pengujian konvensional mampu dideteksi dengan menggunakan peralatan analisis tersebut dengan tingkat akurasi dan presisi yang tinggi.

Instrumentasi kimia memiliki kemampuan mendeteksi pada rentang kadar terendah hingga tertinggi sesuai sensitivitasnya. Kadar terendah suatu analit yang mampu dideteksi oleh instrumentasi kimia disebut level of quantitation (LoQ), sedangkan kadar tertinggi yang mampu dideteksi disebut level of linearity (LoL). Daerah rentang LoQ hingga LoL dari suatu respon instrumentasi kimia disebut daerah rentang kerja yang merupakan regresi linear. Dalam prakteknya, laboratorium lebih sering memprioritaskan penetapan LoQ daripada LoL disebabkan pelaporan hasil pengujian yang mensyaratkan batasan LoQ yang mampu dicapai oleh suatu laboratorium. Laboratorium sebaiknya menetapkan juga LoL sebagai batasan tertinggi kemampuan laboratorium dalam melakukan pengujian analit dengan menggunakan peralatan instrumentasi kimia tertentu. Sehubungan dengan hal tersebut, maka kajian ilmiah ini bertujuan untuk menentukan LoL pengujian air raksa (Mercury, $\mathrm{Hg}$ ) dalam air dan air limbah secara spektrofotometri serapan atom sesuai SNI 6989.78: 2011[1].

Penentuan kadar analit $\mathrm{Hg}$ dalam contoh uji secara kuantitatif dengan SSA dilakukan melalui kurva kalibrasi dengan linearitas yang memenuhi batas keberterimaan. Kurva kalibrasi merupakan grafik yang membentuk garis lurus (linear) yang menyatakan hubungan antara kadar larutan kerja dengan respon yang proporsional dari instrumen yang digunakan. LoL ditetapkan dengan cara melakukan 10 kali pengulangan pengukuran kadar rendah dan kadar tinggi pada rentang kerja metode pengujian. Hasil pengulangan pengujian tersebut dievaluasi secara statistika untuk menentukan batas keberterimaannya.

\section{METODOLOGI}

Metode pengujian air raksa $(\mathrm{Hg})$ dalam air dan air limbah secara SSA uap dingin atau Mercury analyzer sesuai SNI 6989.78: 2011 memiliki kisaran kadar $1 \mu \mathrm{g} \mathrm{Hg} / \mathrm{L}$ sampai dengan $20 \mu \mathrm{g}$ $\mathrm{Hg} / \mathrm{L}$. Secara prinsip, ion $\mathrm{Hg}^{2+}$ direduksi oleh $\mathrm{Sn}^{2+}$ menjadi atom $\mathrm{Hg}$ dan selanjutnya atom tersebut dianalisis secara kuantitatif dengan spektrofotometer serapan atom-uap dingin pada panjang gelombang 253,7 $\mathrm{nm}$.

Penentuan LoL dilakukan melalui pembuatan kurva kalibrasi pada rentang $1 \mu \mathrm{g} \mathrm{Hg} / \mathrm{L}-20$ $\mu \mathrm{g} \mathrm{Hg} / \mathrm{L}$ dengan cara memasukkan $100 \mathrm{~mL}$ larutan standar kerja $\mathrm{Hg}$ pada kadar (1, 2, 4, 8, 10, 15 dan 20) $\mu \mathrm{g} \mathrm{Hg} / \mathrm{L}$ ke dalam masingmasing Erlenmeyer $250 \mathrm{~mL}$. Kemudian tambahkan $5 \mathrm{~mL} \mathrm{H}_{2} \mathrm{SO}_{4}$ pekat dan 2,5 $\mathrm{mL} \mathrm{HNO}_{3}$ pekat kedalam masing-masing Erlenmeyer tersebut, lalu tambahkan 15 
mL larutan $\mathrm{KMnO}_{4}$ dan tunggu sampai 15 menit. Bila warna ungu hilang tambahkan lagi $\mathrm{KMnO}_{4}$ sampai warna ungu tidak hilang. Setelah itu, tambahkan $8 \mathrm{~mL} \mathrm{~K}_{2} \mathrm{~S}_{2} \mathrm{O}_{8}$ dan panaskan dalam penangas air selama 2 jam pada suhu $95^{\circ} \mathrm{C}$, lalu dinginkan sampai suhu kamar. Jika suhu larutan telah dingin, maka tambahkan secukupnya larutan hidroksilamin$\mathrm{NaCl}$ untuk mereduksi kelebihan $\mathrm{KMnO}_{4}$ dan tambahkan $5 \mathrm{~mL} \mathrm{SnCl}_{2}$, Ukur segera kadar $\mathrm{Hg}$ dalam larutan menggunakan SSA uap dingin yang sudah dioptimasikan sesuai petunjuk alat. Hal yang perlu diperhatikan adalah penambahan $\mathrm{SnCl}_{2}$ akan menghasilkan atom $\mathrm{Hg}^{0}$ yang mudah menguap sehingga harus segera ditutup [2-3].

Buat kurva kalibrasi dengan menghubungkan garis linear antara kadar dengan absorbansi yang diperoleh dari respon SSA uap dingin dan hitung persamaan garis regresi linearnya. Jika koefisien linearitas kurva kalibrasi $(r)<0,995$, maka periksa kondisi alat SSA dan ulangi tahapan pembuatan kurva kalibrasi hingga diperoleh nilai $(r) \geq 0,995$. Jika kurva kalibrasi memenuhi batas keberterimaan, maka lakukan 10 kali pengulangan pengukuran untuk kadar rendah $(1 \mu \mathrm{g} \mathrm{Hg} / \mathrm{L})$ dan kadar tinggi $(20 \mu \mathrm{g}$ $\mathrm{Hg} / \mathrm{L}$ ). Hitung masing-masing simpangan baku dan lakukan evaluasi secara statistik dengan menggunakan uji F.

Hasil penentapan LoLHg dengan menggunakan SSA uap dingin dinyatakan diterima apabila kurva linear dengan nilai $(r) \geq 0,995$, dan pada derajat kebebasan $d f_{1}=d f_{2}=n-1$ dengan tingkat kepercayaan 99\%, diperoleh $\mathrm{F}_{\text {hitung }}<$ $\mathrm{F}_{\text {tabel }}$, maka uji $\mathrm{F}$ diterima dan kadar tertinggi pada kurva kalibrasi $20 \mu \mathrm{g} \mathrm{Hg} / \mathrm{L}$ merupakan nilai LoL.

\section{HASIL DAN PEMBAHASAN}

Ruang lingkup metode pengujian air raksa (Mercury, Hg) pada penelitian ini memiliki kisaran kadar $1 \mu \mathrm{g} \mathrm{Hg} / \mathrm{L}$ - $20 \mu \mathrm{g} \mathrm{Hg} / \mathrm{L}$, maka kadar $\mathrm{Hg}$ yang dipilih untuk linearitas kurva kalibrasi ditentukan sebagaimana Tabel 1 dan menghasilkan nilai absorbansi sebagai berikut: Untuk membuktikan linearitas hubungan antara kadar $\mathrm{Hg}$ dengan respon instrumen SSA, maka uji yang paling mudah adalah dengan melihat kurva kalibrasi dalam grafik dan membuat garis linear antar data yang ada. Evaluasi secara visual garis yang terbentuk dapat membuktikan linearitas suatu garis tetapi kelemahannya adalah bersifat subyektif karena berbeda pengamat akan memberikan kesimpulan yang berbeda

Tabel 1. Deret Larutan Kadar Hg dengan Nilai Absorbansi dari SSA

\begin{tabular}{c|c|c}
\hline No. & Kadar $(\mu \mathrm{g} / \mathrm{L})$ & Absorbansi \\
\hline 1 & 1 & 0,0124 \\
2 & 2 & 0,0240 \\
3 & 4 & 0,0481 \\
4 & 8 & 0,0895 \\
5 & 10 & 0,1188 \\
6 & 15 & 0,1702 \\
7 & 20 & 0,2306 \\
\hline \multicolumn{2}{c}{ Slop } & 0,0114 \\
& Intersep & 0,0012 \\
\multicolumn{2}{c}{ Koef. Determinasi $\left(\mathrm{R}^{2}\right)$} & 0,9993 \\
& Koef. Regresi Linear $(\mathbf{r})$ & 0,9996 \\
\hline
\end{tabular}




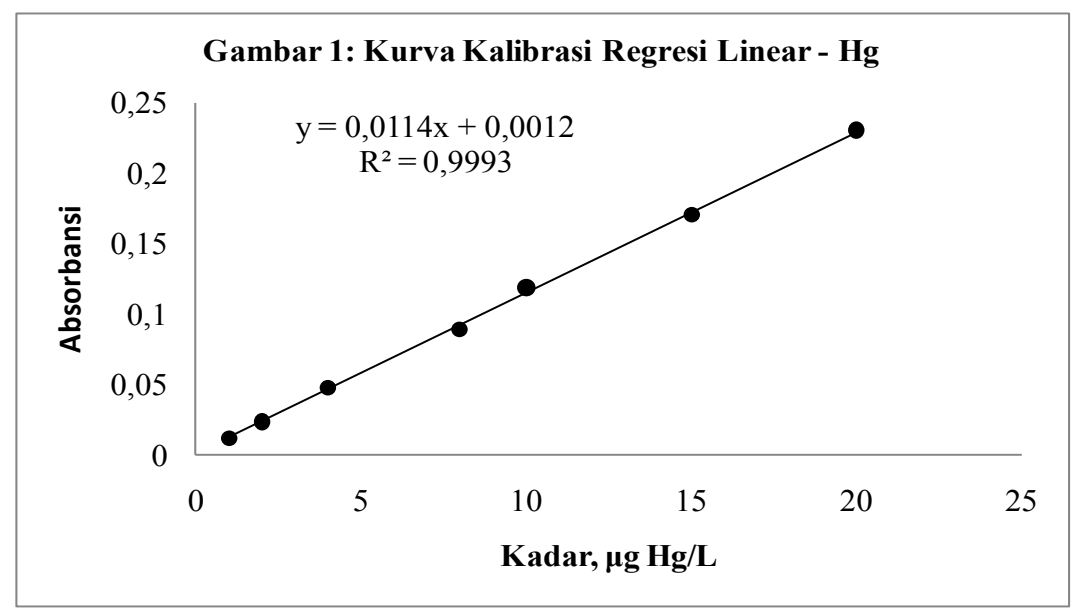

Gambar 1. Uji Linearitas Kurva Kalibrasi Melalui Perbedaan Simpangan Baku Residual

terhadap suatu linearitas. Untuk menghindari hal tersebut, maka digunakan uji linearitas secara statistika dengan menggunakan perbandingan simpangan baku residual yang diperoleh dari perhitungan regresi linear $\left(s d_{y l}\right)$ dengan simpangan baku residual yang diperoleh dari perhitungan regresi non-linear $\left(s d_{y 2}\right)$. Perbedaan varian yang dinotasikan sebagai $\mathrm{DS}^{2}$ dihitung dengan persamaan sebagai berikut ${ }^{[4]}$ :

$$
D S^{2}=(n-2) s d_{y 1}^{2}-(n-3) s d_{y 2}^{2}
$$

dimana:

$$
\begin{aligned}
& \mathrm{DS}^{2}=\text { perbedaan varian } \\
& \mathrm{n} \quad=\begin{array}{c}
\text { jumlah pasangan data antara kadar dengan respon } \\
\text { instrumen SSA }
\end{array} \\
& s d_{y l}=\text { simpangan baku residual regresi linear } \\
& s d_{y 2}=\text { simpangan baku residual regresi non-linear }
\end{aligned}
$$

sedangkan $s d_{y 1}$ dan $s d_{y 2}$ dirumuskan sebagai berikut:

$$
s d_{y 1}=\sqrt{\frac{\sum_{i=1}^{n}\left(y_{i}-\hat{y}_{i 1}\right)^{2}}{n-2}}
$$

dan

$$
s d_{y 2}=\sqrt{\frac{\sum_{i=1}^{n}\left(y_{i}-\hat{y}_{i 2}\right)^{2}}{n-3}}
$$

Untuk mengevaluasi linearitas yang ada, maka $\mathrm{F}_{\text {hitung }}$ ditentukan melalui persamaan sebagai berikut:

$$
F_{\text {hitung }}=\frac{D S^{2}}{s d_{y 2}^{2}}
$$

Nilai $\mathrm{F}_{\text {hitung }}$ yang diperoleh dibandingkan dengan $\mathrm{F}_{\text {tabel }}$, dengan kesimpulan sebagai berikut:

a) jika $F_{\text {hitung }}<\mathrm{F}_{\text {tabel }}$ : garis yang terbentuk adalah regresi linear

b) jika $\mathrm{F}_{\text {hitung }}>\mathrm{F}_{\text {tabel }}$ : garis yang terbentuk adalah regresi non-linear

Untuk mendapatkan nilai $\mathrm{F}_{\text {tabel }}$ maka derajat kebebasan untuk $\mathrm{DS}^{2}$ adalah $\mathrm{df}=$ $\mathrm{n}-1$ dengan tingkat kepercayaan 99\% maka $\mathrm{F}_{\text {tabel }}=\mathrm{F}_{(0,99 ; \mathrm{n}-1 ; \mathrm{n}-1)}$.

Dari gambar 1 diatas, maka hubungan antara kadar $\left(x_{i}\right)$ dan absorbansi $\left(y_{i}\right)$ diplotkan sehingga didapat persamaan regresi linear kurva kalibrasi:

$$
y=0,0114 x+0,0012
$$


Adapun simpangan baku residual regresi linear dihitung dengan persamaan (2) dan diperoleh:

$$
s d_{y 1}=\sqrt{\frac{\sum_{i=1}^{n}\left(y_{i}-\hat{y}_{i 1}\right)^{2}}{n-2}}=0,0024
$$

Untuk mengetahui bahwa garis yang terbentuk merupakan regresi linear maka simpangan baku residual $s d_{y l}$ dibandingkan dengan simpangan baku residual non-linear $s d_{y 2}$. Persamaan regresi non-linear ditentukan dengan persamaan (5):

$y=c x^{2}+b x+a$

Nilai c pada regresi non-linear tersebut ditentukan melalui persamaan sebagai berikut:

$$
c=\frac{\left(Q_{x y} \cdot Q_{x^{3}}\right)-\left(Q_{x^{2} y} \cdot Q_{x x}\right)}{\left(Q_{x^{3}}\right)^{2}-\left(Q_{x x} \cdot Q_{x^{4}}\right)}
$$

dimana:

$$
\begin{aligned}
& Q_{x y}=\sum_{i=1}^{n}\left(x_{i} y_{i}\right)-\left(\sum_{i=1}^{n} x_{i} \frac{\sum_{i=1}^{n} y_{i}}{n}\right) \\
& Q_{x x}=\sum_{i=1}^{n} x_{i}^{2}-\frac{\left(\sum_{i=1}^{n} x_{i}\right)^{2}}{n} \\
& Q_{x^{2} y}=\sum_{i=1}^{n}\left(x_{i}^{2} \cdot y_{i}\right)-\left(\sum_{i=1}^{n} y_{i} \frac{\sum_{i=1}^{n} x_{i}^{2}}{n}\right)
\end{aligned}
$$

$$
\begin{aligned}
& Q_{x^{3}}=\sum_{i=1}^{n} x_{i}^{3}-\left(\sum_{i=1}^{n} x_{i} \frac{\sum_{i=1}^{n} x_{i}}{n}\right) \ldots \\
& Q_{x^{4}}=\sum_{i=1}^{n} x_{i}^{4}-\frac{\left(\sum_{i=1}^{n} x_{i}^{2}\right)^{2}}{n} \ldots . .
\end{aligned}
$$

Maka nilai c dalam persamaan regresi nonlinear adalah:

$$
c=\frac{\left(Q_{x y} \cdot Q_{x^{3}}\right)-\left(Q_{x^{2} y} \cdot Q_{x x}\right)}{\left(Q_{x^{3}}\right)^{2}-\left(Q_{x x^{\prime}} \cdot Q_{x^{4}}\right)}=6,108
$$

Sedangkan nilai b pada regresi non-linear tersebut ditentukan melalui persamaan sebagai berikut:

$$
b=\frac{Q_{x y}-c Q_{x^{3}}}{Q_{x x}}
$$

jadi,

$$
b=\frac{Q_{x y}-c Q_{x^{3}}}{Q_{x x}}=11,29
$$

dan nilai a ditentukan melalui persamaan dibawah ini :

$$
a=\frac{\left(\sum_{i=1}^{n} y_{i}-b \sum_{i=1}^{n} x_{i}-c \sum_{i=1}^{n} x_{i}^{2}\right)}{n}
$$

jadi,

$$
a=\frac{\left(\sum_{i=1}^{n} y_{i}-b \sum_{i=1}^{n} x_{i}-c \sum_{i=1}^{n} x_{i}^{2}\right)}{n}=0,001
$$

Dengan demikian persamaan regresi nonlinear (Gambar 2) adalah:

$y=6,108 x^{2}+11,29 x+0,001$ 


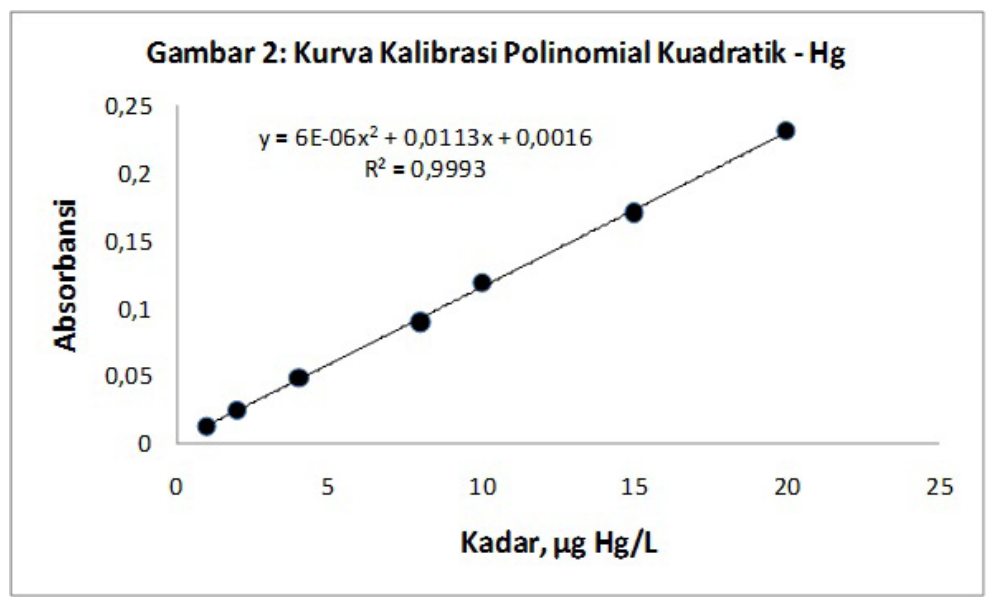

Gambar 2: Non-linearitas Kurva Kalibrasi Mercury

Adapun simpangan baku residual regresi non-linear dihitung dengan persamaan (3), sehingga diperoleh:

$$
s d_{y 2}=\sqrt{\frac{\sum_{i=1}^{n}\left(y_{i}-\hat{y}_{i 2}\right)^{2}}{n-3}}=0,0027
$$

Ketika nilai simpangan baku residual regresi linear $\left(s d_{y l}\right)$ dan simpangan baku residual regresi non-linear $\left(s d_{y l}\right)$ telah ditentukan, maka perbedaan varian yang ditentukan sebagaimana dalam persamaan (1) dan didapatkan:

$$
D S^{2}=(n-2) s d_{y 1}^{2}-(n-3) s d_{y 2}^{2}=3,295 \cdot 10^{-7}
$$

dan $\mathrm{F}_{\text {hitung }}$ ditentukan melalui persamaan (4), sehingga diperoleh:

$$
F_{\text {hitung }}=\frac{D S^{2}}{s d_{y 2}^{2}}=1,528.10^{-8}
$$

Sedangkan $\mathrm{F}_{\text {tabel }}=\mathrm{F}_{(0,99 ; \mathrm{n}-1 ; \mathrm{n}-1)}=\mathrm{F}_{(0,99 ; 9 ; 9)}=$ 5,351 (Tabel 2). Sehubungan dengan $\mathrm{F}_{\text {hitung }}<$ $\mathrm{F}_{\text {tabel }}$ maka kurva kalibrasi tersebut merupakan garis regresi linear.

Tabel 2: Nilai $F_{\text {tabel }}$ untuk $a=0,01$

\begin{tabular}{cccccccccccccc}
\hline df2/df1 & 3 & 4 & 5 & 6 & 7 & 8 & 9 & 10 & 15 & 20 & 30 & INF \\
\hline 3 & 29.457 & 28.710 & 28.237 & 27.911 & 27.672 & 27.489 & 27.345 & 27.229 & 26.872 & 26.690 & 26.505 & 26.125 \\
4 & 16.694 & 15.977 & 15.522 & 15.207 & 14.976 & 14.799 & 14.659 & 14.546 & 14.198 & 14.020 & 13.838 & 13.463 \\
5 & 12.060 & 11.392 & 10.967 & 10.672 & 10.456 & 10.289 & 10.158 & 10.051 & 9.722 & 9.553 & 9.379 & 9.020 \\
6 & 9.780 & 9.148 & 8.746 & 8.466 & 8.260 & 8.102 & 7.976 & 7.874 & 7.559 & 7.396 & 7.229 & 6.880 \\
7 & 8.451 & 7.847 & 7.460 & 7.191 & 6.993 & 6.840 & 6.719 & 6.620 & 6.314 & 6.155 & 5.992 & 5.650 \\
8 & 7.591 & 7.006 & 6.632 & 6.371 & 6.178 & 6.029 & 5.911 & 5.814 & 5.515 & 5.359 & 5.198 & 4.859 \\
9 & 6.992 & 6.422 & 6.057 & 5.802 & 5.613 & 5.467 & 5.351 & 5.257 & 4.962 & 4.808 & 4.649 & 4.311 \\
10 & 6.552 & 5.994 & 5.636 & 5.386 & 5.200 & 5.057 & 4.942 & 4.849 & 4.558 & 4.405 & 4.247 & 3.909 \\
11 & 6.217 & 5.668 & 5.316 & 5.069 & 4.886 & 4.744 & 4.632 & 4.539 & 4.251 & 4.099 & 3.941 & 3.602 \\
15 & 5.417 & 4.893 & 4.556 & 4.318 & 4.142 & 4.004 & 3.895 & 3.805 & 3.522 & 3.372 & 3.214 & 2.868 \\
20 & 4.938 & 4.431 & 4.103 & 3.871 & 3.699 & 3.564 & 3.457 & 3.368 & 3.088 & 2.938 & 2.778 & 2.421 \\
30 & 4.510 & 4.018 & 3.699 & 3.473 & 3.304 & 3.173 & 3.067 & 2.979 & 2.700 & 2.549 & 2.386 & 2.006 \\
F & 3.782 & 3.319 & 3.017 & 2.802 & 2.639 & 2.511 & 2.407 & 2.321 & 2.039 & 1.878 & 1.696 & 1.000 \\
\hline
\end{tabular}




\section{Uji Linearitas Kurva Kalibrasi Melalui} Analysis of Varian (ANOVA)

Pembuktian linearitas kurva kalibrasi dapat juga dilakukan dengan analysis of varian (anova). Jika data pada Tabel 1 dilakukan evaluasi statistika dengan anova, maka akan diperoleh informasi, diantaranya; intersep, slop, koefisien regresi linear dan significance-F sebagai bukti suatu garis dapat dinyatakan memenuhi kriteria regresi linear atau regresi non-linear. Anova dapat dihitung dengan menggunakan program excel sebagaimana ditampilkan dalam Tabel 3.

Jika hasil perhitungan anova memberikan nilai koefisien regresi linear yang diungkapkan sebagai Multiple $R \geq 0,995$ dan nilai $p$-value yang dinyatakan sebagai Significance $F \leq 0,05$ maka garis yang terbentuk merupakan garis regresi linear. Sehubungan dengan kadar deret larutan kerja $\mathrm{Hg}$ dengan absorbansi tersebut menghasilkan nilai Multiple $R=0,9996$ dan nilai Significance $F=5.10^{-09}$, maka dapat disimpulkan bahwa garis yang terbentuk merupakan garis regresi linear.

\section{Uji-F}

Level of linearity merupakan batas kadar tertinggi analit dari suatu metode pengujian tertentu. Rentang kerja metode tersebut harus merupakan garis lurus (linear) yang memenuhi batas keberterimaan statistika. Penetapan LoL adalah sebagai berikut[6]:

a) buat minimum 7 deret kadar larutan kerja tanpa blanko dengan mempertimbangkan rentang pengujian metode yang sedang diverifikasi;

b) buat kurva kalibrasi berdasarkan kadar larutan kerja dengan respon instrumen yang digunakan;

c) lakukan 10 kali pengulangan pengukuran untuk kadar rendah dan kadar tinggi pada larutan kerja tersebut;

d) evaluasi batas keberterimaan secara statistika.

Sehubungan dengan pengujian kadar Mercury dalam air sesuai SNI 6989.78: 2011 memiliki rentang $1 \mu \mathrm{g} \mathrm{Hg} / \mathrm{L}-20 \mu \mathrm{g} \mathrm{Hg} / \mathrm{L}$, maka sesuai tahapan diatas, diperoleh data seperti dalam Tabel 4, sebagai berikut:

Tabel 3: Analysis of Varian (anova) Regresi Linear

\begin{tabular}{|c|c|c|c|c|c|c|}
\hline \multicolumn{7}{|c|}{ SUMMARY OUTPUT } \\
\hline \multicolumn{7}{|c|}{ Regression Statistics } \\
\hline Multiple $R$ & 0,9996 & & & & & \\
\hline R Square & 0,9993 & & & & & \\
\hline Adjusted R Square & 0,9991 & & & & & \\
\hline Standard Error & 0,0024 & & & & & \\
\hline Observations & 7 & & & & & \\
\hline \multicolumn{7}{|l|}{$A N O V A$} \\
\hline & $d f$ & $S S$ & $M S$ & $F$ & Significance $F$ & \\
\hline Regression & 1 & 0,0386 & 0,0386 & 6705,20 & 5,1,E-09 & \\
\hline Residual & 5 & 2,9,E-05 & 5,8,E-06 & & & \\
\hline \multirow[t]{2}{*}{ Total } & 6 & 0,0386 & & & & \\
\hline & Coefficient & andard Error & t Stat & P-value & Lower 95\% & Upper 95\% \\
\hline Intercept & 0,0012 & 0,0015 & 0,8077 & 0,4559 & $-0,0026$ & 0,0051 \\
\hline Concentration & 0,0114 & 0,0001 & 81,8853 & 0,0000 & 0,0111 & 0,0118 \\
\hline
\end{tabular}


Tabel 4: Penentuan LoL untuk Pengujian Mercury Dalam Air (awal)

\begin{tabular}{|c|c|c|c|c|c|c|c|c|c|c|c|}
\hline Kadar $(\mu \mathrm{g} / \mathrm{L})$ & $\mathbf{A b s}_{1}$ & $\mathrm{Abs}_{2}$ & $\mathrm{Abs}_{3}$ & $\mathbf{A b s}_{4}$ & $\mathrm{Abs}_{5}$ & $\mathrm{Abs}_{6}$ & $\mathbf{A b s}_{7}$ & $\mathrm{Abs}_{8}$ & Abs, 9 & $\mathrm{Abs}_{10}$ & $\mathbf{S d}_{\mathrm{Abs}}$ \\
\hline 1 & 0,0124 & 0,0085 & 0,0106 & 0,0075 & 0,0091 & 0,0099 & 0,0118 & 0,0105 & 0,0132 & 0,0129 & 0,0019 \\
\hline 2 & 0,0240 & & & & & & & & & & \\
\hline 4 & 0,0481 & & & & & & & & & & \\
\hline 8 & 0,0895 & & & & & & & & & & \\
\hline 10 & 0,1188 & & & & & & & & & & \\
\hline 15 & 0,1702 & & & & & & & & & & \\
\hline 20 & 0,2306 & 0,2324 & 0,2325 & 0,2317 & 0,2319 & 0,2309 & 0,2303 & 0,2313 & 0,2322 & 0,2312 & 0,0008 \\
\hline
\end{tabular}

Berdasarkan data dalam Tabel 4 tersebut diatas, maka uji-F digunakan untuk membandingkan dua simpangan baku sesuai persamaan (14). Dengan membandingkan kedua simpangan baku data hasil pengulangan pengujian, maka presisi dapat diketahui hampir sama atau beda nyata.

$$
F_{\text {hitung }}=\frac{s d_{1}^{2}}{s d_{2}^{2}}
$$

dengan catatan bahwa $s d_{1}>s d_{2}$

dimana:

$$
\begin{aligned}
& \mathrm{F}_{\text {hitung }}=\text { hasil uji } \mathrm{F} \text { berdasarkan perhitungan } \\
& s d_{1}=\text { simpangan baku yang memiliki nilai lebih besar } \\
& s d_{2}=\text { simpangan baku yang memiliki nilai lebih kecil }
\end{aligned}
$$

Hasil perhitungan $\mathrm{F}_{\text {hitung }}$ dibandingkan dengan nilai kritis dari tabel $\mathrm{F}\left(\mathrm{F}_{\text {tabel }}\right)$. Untuk mendapat nilai kritis dari tabel $\mathrm{F}$ maka derajat kebebasan untuk kedua simpangan baku $s d_{1}$ dan $s d_{2}$ didasarkan kepada:

$d f_{1}=n_{1}-1$

$d f_{1}=n_{1}-1$

dimana:

$$
\begin{aligned}
& d f_{1}=\text { derajat kebebasan pengujian pertama } \\
& d f_{2}=\text { derajat kebebasan pengujian kedua } \\
& n_{1}=\text { jumlah pengulangan pengujian pertama } \\
& n_{2}=\text { jumlah pengulangan pengujian kedua }
\end{aligned}
$$

Jika $\mathrm{F}_{\text {hitung }} \leq \mathrm{F}_{\text {tabel }}$ dengan tingkat kepercayaan 99\% $(\alpha=0,01)$, maka dapat disimpulkan bahwa kedua data hasil pengujian memiliki presisi yang tidak beda nyata. Nilai $\mathrm{F}_{\text {tabel }}$ diperoleh dari tabel $\mathrm{F}$ untuk $\mathrm{F}_{(\alpha ; \mathrm{df} 1 ; \mathrm{df} 2)}$ atau $\mathrm{F}_{\left(0,01 ; \mathrm{n}^{1-1} ; \mathrm{n}^{2}-1\right)}$.

$$
F_{\text {hitung }}=\frac{s d_{1}^{2}}{s d_{2}^{2}}=\frac{(0,008)^{2}}{(0,001)^{2}}=41,475
$$

Dengan derajat kebebasan $d f_{1}=d f_{2}=n-1$ dan tingkat kepercayaan 99\%, maka diperoleh $\mathrm{F}_{\text {tabel }}=\mathrm{F}_{(0,01 ; 9 ; 9)}=5,351$ (Tabel 5). Dari data perhitungan tersebut maka diketahui bahwa $\mathrm{F}_{\text {hitung }}>\mathrm{F}_{\text {tabel. }}$. Dengan demikian dapat disimpulkan bahwa dengan tingkat kepercayaan $99 \%$ maka $1 \mu \mathrm{g} \mathrm{Hg} / \mathrm{L}-20$ $\mu \mathrm{g} \mathrm{Hg} / \mathrm{L}$ merupakan regresi linear namun kadar mercury $20 \mu \mathrm{g} \mathrm{Hg} / \mathrm{L}$ bukan LoL metode. Oleh karena uji-F ditolak dalam penentuan LoL, maka dilakukan pengulangan pengujian mercury pada kadar $20 \mu \mathrm{g} \mathrm{Hg} / \mathrm{L}$ dan menghasilkan data sebagai berikut: 
Tabel 6: Penentuan LoL untuk pengujian Mercury dalam air (revisi)

\begin{tabular}{|c|c|c|c|c|c|c|c|c|c|c|c|}
\hline $\operatorname{Kadar}(\mu \mathrm{g} / \mathrm{L})$ & $\mathbf{A b s}_{1}$ & $\mathrm{Abs}_{2}$ & $\mathrm{Abs}_{3}$ & $\mathrm{Abs}_{4}$ & $\mathrm{Abs}_{5}$ & $\mathrm{Abs}_{6}$ & $\mathbf{A b s}_{7}$ & $\mathrm{Abs}_{8}$ & $\mathrm{Abs}_{9}$ & $\mathbf{A b s}_{10}$ & $\mathbf{S d}_{\mathrm{Abs}}$ \\
\hline 1 & 0,0124 & 0,0090 & 0,0106 & 0,0088 & 0,0091 & 0,0090 & 0,0097 & 0,0105 & 0,0112 & 0,0120 & 0,0013 \\
\hline 2 & 0,0240 & & & & & & & & & & \\
\hline 4 & 0,0481 & & & & & & & & & & \\
\hline 8 & 0,0895 & & & & & & & & & & \\
\hline 10 & 0,1188 & & & & & & & & & & \\
\hline 15 & 0,1702 & & & & & & & & & & \\
\hline 20 & 0,2306 & 0,2309 & 0,2296 & 0,2301 & 0,2299 & 0,2334 & 0,2302 & 0,2290 & 0,2371 & 0,2322 & 0,0024 \\
\hline
\end{tabular}

Simpangan baku hasil pengulangan dibandingkan dan diperoleh:

$$
F_{\text {hitung }}=\frac{s d_{1}^{2}}{s d_{2}^{2}}=\frac{(0,002)^{2}}{(0,001)^{2}}=3,348
$$

Dengan $d f_{1}=d f_{2}=n-1$ dan tingkat kepercayaan $99 \%$ maka diperoleh $\mathrm{F}_{\text {tabel }}=\mathrm{F}_{(0,01 ; 9 ; 9)}=$ 5,351 (Tabel 2) sehingga $\mathrm{F}_{\text {hitung }}<\mathrm{F}_{\text {tabel }}$. Dapat disimpulkan bahwa dengan tingkat kepercayaan 99\% maka $1 \mu \mathrm{g} \mathrm{Hg} / \mathrm{L}-20 \mu \mathrm{g}$ $\mathrm{Hg} / \mathrm{L}$ merupakan regresi linear dan $20 \mu \mathrm{g} \mathrm{Hg} / \mathrm{L}$ merupakan LoL.

\section{SIMPULAN}

Penentuan uji linearitas kurva kalibrasi metode pengujian air raksa (Mercury, Hg) dalam air dan air limbah secara spektrofotometri serapan atom (SSA) uap dingin sesuai SNI 6989.78: 2011 telah dilakukan melalui perbandingan simpangan baku residual regresi linear dengan simpangan baku residual polinomial kuadratik. Pembuktian linearitas kurva kalibrasi dilakukan dengan analysis of varian (anova). Perolehan nilai Multiple $R$ $=0,9996$ dan nilai Significance $F=5.10^{-09}$, membuktikan bahwa garis yang terbentuk dari kurva kalibrasi merupakan garis regresi linear.
Hasil pengulangan pengukuran $10 \mathrm{kali}$ dilakukan pada kadar rendah $(1 \mu \mathrm{g} \mathrm{Hg} / \mathrm{L})$ dan kadar tinggi $(20 \mu \mathrm{g} \mathrm{Hg} / \mathrm{L})$ untuk menghitung simpangan baku dan diperoleh $\mathrm{F}_{\text {hitung }}=3,348$. Dengan derajat kebebasan $d f_{1}=d f_{2}=n-1$ dan tingkat kepercayaan $99 \%$ maka diperoleh $\mathrm{F}_{\text {tabel }}$ $=\mathrm{F}_{(0,01 ; 9 ; 9)}=5,351$, artinya $\mathrm{F}_{\text {hitung }}<\mathrm{F}_{\text {tabel }}$ maka dapat disimpulkan bahwa $1 \mu \mathrm{g} \mathrm{Hg} / \mathrm{L}-20 \mu \mathrm{g}$ $\mathrm{Hg} / \mathrm{L}$ merupakan regresi linear dan $20 \mu \mathrm{g} \mathrm{Hg} / \mathrm{L}$ merupakan level of linearity (LoL).

\section{DAFTAR PUSTAKA}

(1) Standar Nasional Indonesia, SNI 6989.78: 2011, Air dan Air limbah - Bagian 78: Cara Uji Raksa (Hg) secara Spektrofotometri Serapan Atom (SSA) - Uap Dingin atau Mercury Analyzer.

(2) Standard Methods, Examination of Water and Wastewater 21st Edition, 2005, Method 3112.

(3) ASTM D 3223, "Standard test method for total mercury in water".

(4) International Standard, ISO 8466-1, 1990, "Water Quality - Calibration and Evaluation of Analytical Methods and Estimation of Performance Characteristics" Part 1: Statistical Evaluation of the Linear Calibration Function. 
(5) International Standard, ISO 8466-2, 1993, "Water Quality - Calibration and Evaluation of Analytical Methods and Estimation of Performance Characteristics" Part 2y: Calibration Strategy for Non-Linear Second Order Calibration Function.
(6) Hadi, Anwar, 2009, "Verifikasi Metode Pengujian Parameter Kualitas Lingkungan”, Jakarta. Kementerian Lingkungan Hidup. 